\title{
Evaluation of Middle Ear and Mastoid Cells of COVID-19 Patients
}

\author{
COVID-19 Hastalarının Orta Kulak ve Mastoid Hücrelerinin Değerlendirilmesi
}

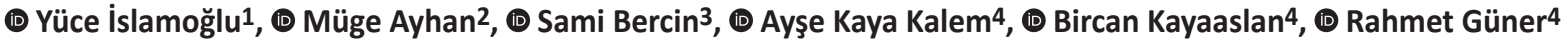 \\ ${ }_{1}^{1}$ Ankara City Hospital, Clinic of Otolaryngology, Ankara, Turkey \\ ${ }^{2}$ Ankara City Hospital, Clinic of Infectious Diseases and Clinical Microbiology, Ankara, Turkey \\ ${ }^{3}$ Ankara Yıldırım Beyazıt University Faculty of Medicine, Department of Otolaryngology, Ankara, Turkey \\ ${ }^{4}$ Ankara Yıldırım Beyazıt University Faculty of Medicine, Department of Infectious Diseases and Clinical Microbiology, Ankara, Turkey
}

\section{Abstract}

Objectives: Severe acute respiratory syndrome coronavirus-2 (SARS-CoV-2) is isolated as the cause of coronavirus disease-2019 (COViD-19). Middle ear and mastoid air cells are covered with the airway mucosa. In COViD-19, an involvement occurs in the airway mucosa; however, although the involvement of eustachian tube covered with this mucosa, middle ear, and mastoid is not known, there can be an intervention. The aim of the study is to investigate the findings of temporal tomography and evaluate the middle ear and mastoid in COVID-19.

Materials and Methods: A retrospective observational study was planned. Patients with a positive polymerase chain reaction (PCR) test for SARSCoV-2 and diagnosed with COVID-19 were included in the study. COVID-19 patients, who had temporal bone tomography scans (CT), were evaluated. One hundred twenty-nine COVID-19 patients with positive PCR, who also had temporal bone scans, were included in the study. A grading system was used to evaluate the effusion in the middle ear and mastoid cells. According to this grading system, left and right middle ear and mastoid were evaluated separately. In the grading system, the scores were evaluated as $0=$ no effusion, $1=$ partial effusion, and $2=100 \%$ effusion. The maximum score was accepted as 8. Bilateral tympanic membranes of all the patients were normal.

Results: Involvement was observed in three patients. Bilateral partial effusion and middle ear involvement were observed in two patients. In one patient, bilateral partial mastoid and unilateral partial middle ear involvement was detected. Temporal CTs of other patients were normal.

Conclusion: No specific finding was found regarding temporal bone involvement from the temporal CT. Three patients had effusion in the middle ear and mastoid. SARS-CoV-2 generally does not affect the temporal bone; however, it rarely causes effusion in the mastoid and middle ear.

Key Words: COVID-19, Temporal Bone, SARS-CoV-2, Mastoid, Middle Ear, Ear Effusion

\section{$\ddot{0} z$}

Amaç: Şiddetli akut solunum yolu sendromu koronavirüsü-2 (SARS-CoV-2), koronavirüs hastalığı-2019 (COVID-19) hastalığının nedeni olarak izole edilmiştir. Orta kulak ve mastoid hücreler hava yolu mukozası ile örtülüdür. COVID-19'da hava yolu mukozasında tutulum meydana gelir, ancak bu mukoza ile örtülü östaki tüpü, orta kulak ve mastoid tutulumunun olduğu bilinmemekle birlikte etkilenme olabilir. Çalışmada amacımız COVID19 'daki temporal kemik tomografisini inceleyerek orta kulak ile mastoid bölümün durumunu incelemektir.

Gereç ve Yöntem: Retrospektif gözlemsel bir çalışma planlandı. SARS-CoV-2 polimeraz zincir reaksiyonu (PCR) testi pozitif olup, COVID-19 tanıSı olan hastalar çalışmaya dahil edildi. COVID-19 hastalarından temporal tomografisi (BT) olanlar değerlendirildi. Çalışmaya temporal BT'si olan 129 PCR pozitif COVID-19 hasta dahil edildi. Orta kulak ve mastoid hücrelerdeki efüzyonu değerlendirmek için bir evreleme sistemi kullanıldı. Bu evreleme sistemine göre sağ ve sol orta kulak ile mastoid ayrı ayrı değerlendirildi. Sıfır puan=efüzyon yok, 1 puan=parsiyel efüzyon ve 2 puan=\%100 efüzyon olarak değerlendirildi. Maksimum skor 8 olarak değerlendirildi. Hastaların iki tarafıı kulak zarı normaldi.

Bulgular: Üç hastada tutulum izlendi. İki hastada bilateral parsiyel efüzyon ve orta kulak tutulumu izlendi. Bir hastada ise bilateral parsiyel mastoid ve tek taraflı parsiyel orta kulak tutulumu izlendi. Diğer hastaların temporal BT'leri normaldi.

Sonuç: Temporal kemik tutulumuna ait temporal tomografide spesifik bir bulgu saptanmadı. Üç hastada orta kulak ve mastoidde efüzyon saptandı. SARS-CoV-2 genellikle temporal kemiği etkilememektedir, ancak nadir olarak mastoid ve orta kulakta efüzyona neden olmaktadır.

Anahtar Kelimeler: COVID-19, Temporal Kemik, SARS-CoV-2, Mastoid, Ortak Kulak, Kulak Efüzyonu

Address for Correspondence/Yazışma Adresi: Yüce İslamoğlu,

Ankara City Hospital, Clinic of Otolaryngology, Ankara, Turkey

Phone: +90 5435042498 E-mail: yuceislamoglu@gmail.com ORCID ID: orcid.org/0000-0002-1294-7088

Received/Geliş Tarihi: 29.11.2020 Accepted/Kabul Tarihi: 04.01.2021

๑Copyright 2021 Ankara University Faculty of Medicine

Journal of Ankara University Faculty of Medicine is published by Galenos Publishing House.

All content are under CC BY-NC-ND license. 


\section{Introduction}

A novel coronavirus, called as severe acute respiratory syndrome coronavirus-2 (SARS-CoV-2), was identified as the cause of an acute respiratory disease in Wuhan, China. The number of cases had increased, and the disease spread all around the worldwide. World Health Organization (WHO) named this new disease as coronavirus disease-2019 (COVID-19). COVID-19 was declared as a pandemic by WHO in March 2020.

The frequently observed symptoms are fever, cough, and as a result of pneumonia, difficulty in breathing but there is a lot of obscurities regarding the disease. The disease generally settles in the lungs; however, the nose and nasopharynx are shown to be the reservoirs for high concentrations of the SARS-CoV-2 $(1,2)$.

Middle ear and mastoid air cell system are covered by respiratory mucosa. In COVID-19, an involvement occurs in the airway mucosa, however, although the involvement of eustachian tube covered with this mucosa, middle ear, and mastoid is not known, there can be an intervention $(3,4)$.

Rhinovirus, respiratory syncytial virus, and coronavirus as respiratory viruses have been implicated as potential agents of acute otitis media. Acute otitis media is an inflammatory process of the middle ear associated with an effusion. Middle ear and mastoid air cell inflammation result effusion, and the effusion can be detected via computed tomography (CT) (5-7).

Viral infections can cause congenital or acquired, unilateral or bilateral hearing loss. They can directly damage inner ear structures, can stimulate inflammatory responses, cause inner ear damage, or can result in secondary bacterial or fungal infection that leads to hearing loss. In general, the viruses cause sensorineural hearing loss, but conductive and mixed hearing loss can also be seen. In a study, it was shown that cochlear hair cells can get damaged in COVID-19; however, the mechanism is unclear (8-11).

There is limited information about the effect of SARS-CoV-2 virus on ear, such as does the virus effect mastoid cells and middle ear like other coronaviruses, does it cause otitis media or effusion, or is there any radiological finding in mastoid or middle ear or cochlea?

In the present study, the temporal scan of the COVID-19 positive patients is investigated.

\section{Materials and Methods}

The study was a retrospective observational study. The study group consisted of 129 patients. The patients with COVID-19 infection via a positive polymerase chain reaction (PCR) test were evaluated. One hundred twenty-nine subjects were included in the study, who were decided by the pandemic infection control committee due to the accompanying symptoms. Temporal bone scan was applied for all the patients. This scan did not add any extra radiation or cause any extra time in the tomography. Ethical approval was obtained from Ankara City Hospital No.1 Clinical Research Board with number El-20-726.

The patients with a history of chronic otitis media, ear surgery, other active infections besides COVID-19, hearing loss, smoking, or vertigo were excluded from the study. A grading system for evaluating the effusion in middle ear and mastoid was used to evaluate the images (12).

These scores were applied for left or right mastoid cells and left or right middle ear separately and in a validating grading system, the scores were defined as $0=$ no effusion, $1=$ partial effusion, $2=$ and $2=100 \%$ effusion. Maximum total score was 8 .

The patients were divided in two groups according to the chest CT findings. Group 1 (78 patients) had typical radiological signs for COVID-19 and group 2 (51 patients) had negative signs of COVID-19. Groups were compared for grading scores.

\section{Statistical Analysis}

Data were analyzed by using the SPSS version 21.0 software program (Statistical Package for Social Sciences v.21, IBM, Chicago, IL). Paired simple t-test was used for the comparison of group 1 and group 2 in terms of grading score. $P<0.05$ was considered statistically significant.

\section{Results}

A total of 129 hospitalized patients who were confirmed PCR positive for COVID-19 and had a temporal CT scans were included to this study.

The mean age was 43.3 (standard deviation \pm 18.51 ; minmax 19-83 years). Of 129 patients, 78 (60.5\%) were male and 51 (39.5\%) were female. Patients were divided into two groups according to their chest CT findings. Group 1 had specific chest CT findings and included 78 patients, group 2 had no findings in chest CT and included 51 patients. There was no difference in the female/male proportion between groups $(p=0.611)$. There was no difference between the groups regarding comorbid diseases except obesity. Group 1 had a statistically high obesity (Table 1). There was no difference between the groups for the onset symptoms of disease except postnasal drip (Table 2). Postnasal drip was significantly high in group 2 .

All patients had normal tympanic membrane. Bilateral partial middle ear and mastoid cavity involvement were observed in the temporal bone scan of two patients. The score of these patients was 4. One patient had bilateral partial mastoid and unilateral middle ear involvement. The score of the patient was 3 .

One patient, who had a score of 4 , was in group 1 and other two patients were in group 2. Other patients had normal 
temporal bone $\mathrm{CT}$ images. Findings of the temporal bone scans were compared according to the grading system between the groups and there was no significant difference between the groups $(p=0.258$ ) (Table 3 ).

\section{Discussion}

SARS-CoV-2 virus is found in high concentrations in the nose and nasopharynx. Nasopharynx has a close relationship with mastoid cells and middle ear. Airway mucosa is involved in COVID-19. Middle ear, eustachian tube, and mastoid cells are covered by airway mucosa that is involved in COVID-19. Due to these findings, ear might be contaminated, but further evidence is required $(1,13,14)$.

It is known that coronaviruses have a role in acute otitis media and upper respiratory tract infections. Effusion is often seen in acute otitis media and upper respiratory tract infections. This effusion can be seen in the radiological examination of the middle ear and mastoid cells. There is limited information about the middle ear involvement of SARS-CoV-2. Virus involvement might cause otitis media similar to other coronaviruses and this can be observed in radiological scan $(6,14,15)$. Recently, a cadaver study was published, and it was seen that SARS-CoV-2 virus was isolated from the middle ear and mastoid of the cadavers with COVID-19 (16).

The evaluation of the hearing loss pathogenesis of COVID-19 draws attention and needs further studies and more evidence. Middle ear and mastoid cavity may be an important route of infection. Virus may affect the middle ear, inner ear, or mastoid cells and cause hearing loss which may be detected by temporal bone scan. However, there is no study regarding the temporal bone scan of COVID-19.

In the present study, middle ear and mastoid condition was evaluated by using temporal bone tomography scans of COVID-19 patients. The current study is the first study investigating middle ear and mastoid from the temporal CT's in COVID-19.

No specific involvement was found from the temporal CTs. Two patients had bilateral partial effusion in middle ear

\begin{tabular}{llll}
\hline $\begin{array}{l}\text { Table 1: Additional diseases of the study population } \\
\text { Group 1 (Positive CT) } \\
\mathbf{n = 7 8}\end{array}$ & $\begin{array}{l}\text { Group 2 (Negative CT) } \\
\mathbf{n = 5 1}\end{array}$ & $\mathbf{p}$ \\
\hline Additional disease & & 5 & $0.202^{\star}$ \\
\hline Diabetes mellitus & 14 & 9 & $0.965^{\star}$ \\
\hline Hypertension & 14 & 3 & $0.581^{\star}$ \\
\hline Coronary artery disease & 3 & 0 & $0.155^{\star}$ \\
\hline Malignancy & 4 & 6 & $0.012^{\star}$ \\
\hline Obesity & 24 & 0 & $0.152^{\star}$ \\
\hline Chronic heart failure & 4 & & (4)
\end{tabular}

Table 2: Symptoms of the study population

\section{Group 1 (Positive CT) $n=78$}

Symptoms

Fever

Cough

Postnasal drip

Rhinorrhea

Myalgia

^Student t-test, CT: Computed tomography

\section{Group 2 (Negative CT) \\ $n=51$}

$\begin{array}{ll}26 & 19 \\ 36 & 19 \\ 15 & 18 \\ 3 & 6 \\ 43 & 27\end{array}$

19

19

18

6
27 p

$0.648^{\star}$
$0.316^{\star}$
$0.041^{\star}$
$0.084^{\star}$
$0.807^{\star}$

Table 3: Comparison of the temporal grading of the study population

\section{Group 1 (Positive CT)}

$\mathrm{n}=78$

Temporal CT findings

Temporal grading

Mean

0.051

\section{Group 2 (Negative CT)}

$\mathrm{n}=51$

Mean

0.13

\section{p}

$0.258^{\star}$ 
and mastoid and one patient had bilateral mastoid cells, and unilateral middle ear effusion. Other patients had normal and healthy temporal CT scans.

Limitations of the study are the retrospective design, limited number of patients in the study groups, and the lack of the hearing tests of the patients. The reason that COVID-19 is very contagious, a prospective study, which performs the temporal bone tomography scan together with a hearing test for all the patients, could not be designed.

\section{Conclusion}

There were three patients with the signs of effusion in mastoid air cells or middle ear. There was no specific sign in the temporal CTs. We found that SARS-CoV-2 rarely affects the ear but further studies with larger population groups, detailed hearing tests, cochlear and inner ear evaluations will be useful for the evaluation of the etiology of hearing loss in COVID-19 and ear involvement.

\section{Ethics}

Ethics Committee Approval: Ethical approval was obtained from Ankara City Hospital No.1 Clinical Research Board with number El-20-726.

Informed Consent: The study was a retrospective observational study.

Peer-reviewed: Externally and internally peer-reviewed.

\section{Authorship Contributions}

Surgical and Medical Practices: Y.I., M.A., S.B., Concept: S.B., R.G., B.K., Design: Y.I., M.A., S.B., R.G., Data Collection or Processing: Y.I., M.A., A.K.K., B.K., Analysis or Interpretation: Y.̇.., M.A., A.K.K., B.K., Literature Search: Y.I., M.A., S.B., A.K.K., B.K., R.G., Writing: Y.I., M.A., S.B., R.G.

Conflict of Interest: No conflict of interest was declared by the authors.

Financial Disclosure: The authors declared that this study has received no financial support.

\section{References}

1. Zou L, Ruan F, Huang M, et al. SARS-CoV-2 Viral Load in Upper Respiratory Specimens of Infected Patients. N Engl J Med. 2020;382:1177-1179.

2. Van Doremalen N, Bushmaker T, Morris DH, et al. Aerosol and Surface Stability of SARS-CoV-2 as Compared with SARS-CoV-1. N Engl J Med. 2020;382:1564-1567.

3. Givi B, Schiff BA, Chinn SB, et al. Safety Recommendations for Evaluation and Surgery of the Head and Neck During the COVID-19 Pandemic. JAMA Otolaryngol Head Neck Surg. 2020;146:579-584.

4. Chen JX, Workman AD, Chari DA, et al. Demonstration and Mitigation of Aerosol and Particle Dispersion During Mastoidectomy Relevant to the COVID-19 Era. Otol Neurotol. 2020;41:1230-1239.

5. Heikkinen $\mathrm{T}$, Thint $\mathrm{M}$, Chonmaitree $\mathrm{T}$. Prevalence of various respiratory viruses in the middle ear during acute otitis media. N Engl J Med. 1999;340:260-264.

6. Pitkäranta A, Virolainen A, Jero J, et al. Detection of rhinovirus, respiratory syncytial virus, and coronavirus infections in acute otitis media by reverse transcriptase polymerase chain reaction. Pediatrics. 1998;102:291-295.

7. Brennan TE, Saadia-Redleaf Ml. Occult middle ear and mastoid fluid in acute otitis externa. Laryngoscope. 2012;122:2067-2070.

8. Adler SP. Congenital cytomegalovirus screening. Pediatr Infect Dis J. 2005;24:1105-1106.

9. Al Muhaimeed H, Zakzouk SM. Hearing loss and herpes simplex. J Trop Pediatr. 1997;43:20-24.

10. Chandrasekhar SS, Connelly PE, Brahmbhatt SS, et al. Otologic and audiologic evaluation of human immunodeficiency virus-infected patients. Am J Otolaryngol. 2000;21:1-9.

11. Mustafa MWM. Audiological profile of asymptomatic Covid-19 PCRpositive cases. Am J Otolaryngol. 2020;41:102483.

12. Huyett $P, \operatorname{Raz} Y$, Hirsch $B E$, et al. Radiographic Mastoid and Middle Ear Effusions in Intensive Care Unit Subjects. Respir Care. 2017;62:350-356.

13. Cetinkaya EA. COVID-19 Pandemic and Otologic Surgery. J Craniofac Surg. 28 May 2020.

14. Saadi RA, Bann DV, Patel VA, et al. A Commentary on Safety Precautions for Otologic Surgery during the COVID-19 Pandemic. Otolaryngol Head Neck Surg. 2020;162:797-799.

15. Chen N, Hou Q, Cui Z, et al. Effect of otitis media with effusion and its clinical intervention on the development of mastoid in children. Acta Otolaryngol. 2014;134:481-484.

16. Frazier KM, Hooper JE, Mostafa HH, et al. SARS-CoV-2 Virus Isolated From the Mastoid and Middle Ear: Implications for COVID-19 Precautions During Ear Surgery. JAMA Otolaryngol Head Neck Surg. 2020;146:964-966. 